Article

\title{
Key Development Factors of Hydrothermal Processes in Germany by 2030: A Fuzzy Logic Analysis
}

\author{
Daniel Reißmann ${ }^{1, *}$, Daniela Thrän ${ }^{1,2}$ and Alberto Bezama ${ }^{1}$ \\ 1 Helmholtz-Centre for Environmental Research - UFZ, Permoserstraße 15, 04318 Leipzig, Germany; \\ daniela.thraen@ufz.de (D.T.); alberto.bezama@ufz.de (A.B.) \\ 2 Deutsches Biomasseforschungszentrum gemeinnützige $\mathrm{GmbH}$, Torgauer Straße 116, \\ 04347 Leipzig, Germany \\ * Correspondence: daniel.reissmann@ufz.de (D.R.); Tel.: +49-341-235-1267
}

Received: 9 November 2018; Accepted: 14 December 2018; Published: 19 December 2018

check for updates

\begin{abstract}
To increase resource efficiency, it is necessary to use biogenic residues in the most efficient and value-enhancing manner. For high water-containing biomass, hydrothermal processes (HTP) are particularly promising as they require wet conditions for optimal processing anyway. In Germany, however, HTP have not yet reached the industrial level, although suitable substrates are available and technological progress has been made in previous years. This study aims to determine why this is by identifying key factors that need to occur HTP development in Germany until 2030. By using results of previous analyses within this context (i.e., literature review, SWOT analysis, expert survey, and focus group workshop) and combining them with the results of an expert workshop and Delphi-survey executed during this analysis, a comprehensive information basis on important development factors is created. Fuzzy logic is used to analyze these factors in terms of interconnections, relevance, and probability of occurrence by 2030. The results show that technological factors, such as a cost-efficient process water treatment and increased system integration of HTP into bio-waste and wastewater treatment plants, are given high relevance and probability of occurrence. The adaptation of the legal framework, for example, the approval of end products from HTP as standard fuels, has very high relevance but such adaptions are considered relatively unlikely.
\end{abstract}

Keywords: hydrothermal processes; Germany; fuzzy Delphi method; fuzzy logic cognitive map

\section{Introduction}

The German government has set a target of reducing the country's annual greenhouse gas emissions (GHG) by 50\% in 2030 compared to the 1990 level [1]. To achieve this goal, it is necessary to use scarce resources more sustainably, which also includes a more efficient use of biogenic residues. However, currently, considerable amounts of biogenic residues and waste are being inefficiently used or not used in Europe [2,3]. The treatment of wet and sludgy biomass is particularly challenging, as it requires energy- and cost-intensive pre-treatment processes (e.g., drying, thickening, sanitization) to become suitable for conventional biomass treatment paths (e.g., pyrolysis) [4]. However, to enhance resource efficiency by sustainably utilizing residues and therefore, fostering progress towards a circular and bio-based economy, it is worth striving for value-added use of such materials. This could also reduce costs (e.g., for more expensive primary materials) and GHG (e.g., by substituting the energetic use of fossil resources), save scarce natural resources (e.g., by recycling of nutrients like phosphorus out of the residual flows) and thus promote climate protection [5-8].

For the last few years, hydrothermal processes (HTP) have gained attention as promising technologies to manage wet biomass. HTP transform wet substrates into gaseous, liquid, or solid high carbon and energy containing products via thermochemical conversion. The products can be 
used for several purposes, like direct use for energy production or as an intermediate for producing agricultural and pharmaceutical chemicals $[4,9,10]$. For optimal operation, HTP need high water containing substrates, which is why residues like sewage sludge and animal excreta are particularly suitable $[9,11]$.

Depending on the operational conditions, different HTP types occur. At temperatures between 160 and $250{ }^{\circ} \mathrm{C}$, pressure conditions between 10 to $30 \mathrm{bar}$, and a residence time between 1 to $72 \mathrm{~h}$, hydrothermal carbonization (HTC) takes place. HTC is a coalification process that converts biomass into hydro-char [12] to be used for energetic purposes, material applications, and as fertilizer or soil conditioner [13]. At slightly higher temperatures (180 to $400{ }^{\circ} \mathrm{C}$ ) and pressures (40 to 200 bar) but lower residence times (10 to $240 \mathrm{~min}$ ), hydrothermal liquefaction (HTL) occurs. HTL is a process that transforms biomass into chemicals and bio-oils [14]. The products can be used for energy production and chemical industry [9]. At supercritical conditions ( 375 to $500{ }^{\circ} \mathrm{C}, 230$ to 400 bar) hydrothermal gasification (HTG) takes place which usually needs less than $10 \mathrm{~min}$ for the reaction. Through HTG biomass is converted into gaseous materials, especially methane and hydrogen, which are used for energy and chemical industry [15].

Compared with other generally suitable biomass conversion processes (e.g., torrefaction, pyrolysis, composting), HTP have some advantages. Compared to torrefaction, for example, HTC products can achieve a higher energy density, energy yield, and combustion reactivity [16]. Additionally, HTC can provide economic advantages. For example, a comparative study of HTC, anaerobic digestion, and composting on the conversion of food waste showed that HTC performs economically best due to its low residence time and less substrate pre-treatment [17]. Another study showed that the HTL of algae can be advantageous compared to pyrolysis in terms of conversion yields and energy conversion rates [18].

At a first glance, HTP seem well suited to the conversion of wet biomass into high carbon and energy-containing products. Nevertheless, as a trade registry evaluation on HTP companies in Germany showed, so far, the technology has not prevailed in Germany. Based on this, since 2008, only a handful of new company foundations have been registered. This is in contrast with the general interest in these processes, which can be measured in terms of the level of research and technological progress. For example, according to a recent study, there are currently 15 patents on HTC in Germany [19]. Also, scientific interest in HTP is continuously increasing. According to Kruse and Dahmen [20], numerous published studies in Scopus since 2009 contain the keywords "supercritical gasification", "hydrothermal liquefaction", and "hydrothermal carbonization". This ongoing interest indicates that there is still high potential for HTP to become an innovative biomass conversion path. This has also been confirmed by international developments. Research activities on HTP are a core issue of the Pacific Northwest National Laboratories in the U.S., where some pilot plants are also in operation [21-23]. In addition, TerraNova Energy operates a larger HTC plant in China [24] and Ingelia in Spain [25].

Also, key metrics on HTP (e.g., the higher heating value (HHV) of products, the energy and mass balance of processes, the carbon efficiency, and the specific investment and operating costs) indicate that there is potential for HTP to be further developed at a large scale. For example, the HHV of hydro-coal ranges from $24 \mathrm{MJ} / \mathrm{kg}$ (median) to $26 \mathrm{MJ} / \mathrm{kg}$ (maxima) [25-27]. In terms of the energy efficiency of HTC (including all energetic losses during the process and without a utilization step) there is also high variation-between 62 per cent (median) and 77 per cent (maximum) [28-30].

However, optimization of the technological, economic, and ecological features of HTP depends on many parameters, such as heat recovery, applied catalysts, substrates used and their moisture content, logistics as well as plant sizes [4]. An example is the connection between HTC plant sizes and investment costs based on the manufacturers' information. The specific investment costs tend to decrease in relation to the capacity of the plants per additional ton of fresh matter biomass input (from $260 \mathrm{EUR} /$ ton for 5000 tons capacity up to $50 \mathrm{EUR} /$ ton for 80,000 tons capacity) [31-34]. So, economies of scale can be already observed. Further, learning curve and scale effects through more experience in the operation of plants on an industrial scale are crucial to achieving gradual optimization of 
essential parameters. Finally, if the parameters can be optimized, HTP will provide several advantages. For example, the HHVs of the final products are generally higher than those of fossil reference systems [4]. Greenhouse gas savings compared to fossil references may also be significant, depending on the substrate used, the energy balance, and the subsequent product use [4].

So far, only a few studies have provided information on the future development of HTP in Germany and Europe as well as the corresponding key factors. A study of the German National Academy of Science and Engineering analyzed the potential system contributions of HTC and HTL to the flexibility of a renewable energy system until 2023 in Germany [35]. It was identified that the approval of HTC coal as a standard fuel and a corresponding fuel standard are of high importance. Furthermore, they recommended the promotion of nutrient recycling and the development of a cost-effective process water treatment procedure. They suggested the use of hydro-coal as an energy carrier, soil additive, and industrial carbon carrier. For HTL it is considered critical that in Germany, algae, which is a particularly suitable substrate, is largely missing. Nevertheless, they recommend the support of nutrient recycling and the increase in quality of the liquid product [35]. De Mena Pardo et al. [19] outlined the necessary factors for the establishment of HTC at the European level, such as the abolition of the waste status of HTC products from waste biomass. They predicted that hydro-coal will first become established on the energy markets and, in the long term, will also occupy material markets. In terms of establishment in the energy sector, however, the "end of the waste" characterization is crucial. Another recent paper [20] identified the integration of HTP into bio-refineries as important future development strategy to generate synergies. Furthermore, the whole value-chain must be addressed, also including stakeholders who have so far only been marginally involved, like farmers. In a previous paper, we used a SWOT analysis to identify the most important current barriers and possibilities for HTP in Germany [36]. The results indicated that the technological readiness of the plant, including the presence of high energy and material efficiency as well as the presence of a suitable process water treatment procedure are factors of high importance. In addition, the overall costs for producing the end-product and the competitive nature of sales markets are seen as important threats. Also, the GHG are of high relevance throughout the process and can be primarily viewed as an opportunity if HTP can mobilize their potential for emission savings as compared with fossil reference systems.

However, although HTP has some promising features as a resource efficient conversion technology for wet biomass, no scaling-up is happening in Germany. Thus, this study aims to identify and prioritize key development factors for HTP that should occur in Germany by 2030 and points out their interconnections using a structured expert participation process. Furthermore, the probability of occurrence of these factors is estimated. This study also aims to provide important information on barriers that must be dealt with to allow HTP to contribute to climate and resource protection in the future.

Specifically, we used the Fuzzy Delphi Method (FDM) and Fuzzy Cognitive Mapping (FCM) in this study. The Delphi method is a forecasting procedure based on the opinions of anonymous experts collected through a multi-stage survey process. It aims to systematically foster expert consensus about uncertain developments [37]. A Delphi survey consists of several rounds of interviews. The first round usually asks for the assessment of uncertain factors and events. The following rounds then ask the experts to revise or confirm their assessments based on the results of the previous rounds [38]. As this method contains some disadvantages (e.g., relatively low consistency of expert opinions, high enforcing effort, and sometimes modifications to individual opinions in order to reach consistent total opinions), we expanded it by using the Fuzzy Delphi Method (FDM) for the final evaluation. With FDM, expert opinions are integrated with fuzzy numbers based on the cumulative frequency distribution and fuzzy integrals. Thus, FDM applies triangulation statistics to determine the distance between the levels of consensus within the expert panel [39]. Furthermore, the FDM needs just a small survey panel to deliver reliable results—an advantage for studies with a small number of suitable participants [40]. FCM is a model consisting of nodes that indicate the most relevant factors (in FCM 
the term "concepts" is used) of a decisional environment and relationships between them (arcs and edges). The analytical background of FCM is based on the structure and function of concept maps, including graph theory-based analyses of pairwise structural relationships between the model factors. It is therefore a decision-support tool which originated a combination of fuzzy logic and artificial neural network theory [41]. It aims to define the important factors relevant to a specific community and the relationships between them as well as optionally testing scenarios in which these factors are varied to see how the system might react under a set of possible conditions [42]. An adjacency matrix $A$ represents the interconnections between model factors. On that basis, the number and directions of edge relations are transformed into quantitative values between -1 (inhibitory effect) and +1 (positive effect) [43]. In particular, FCM can be used to model complex systems with high uncertainty and less available empirical data [44], which, based on our experiences within this working field, is the case for this study's topic.

\section{Materials and Methods}

The key factors were primarily developed based on qualitative and quantitative expert evaluations and information from relevant literature. Figure 1 gives an overview of the study design.

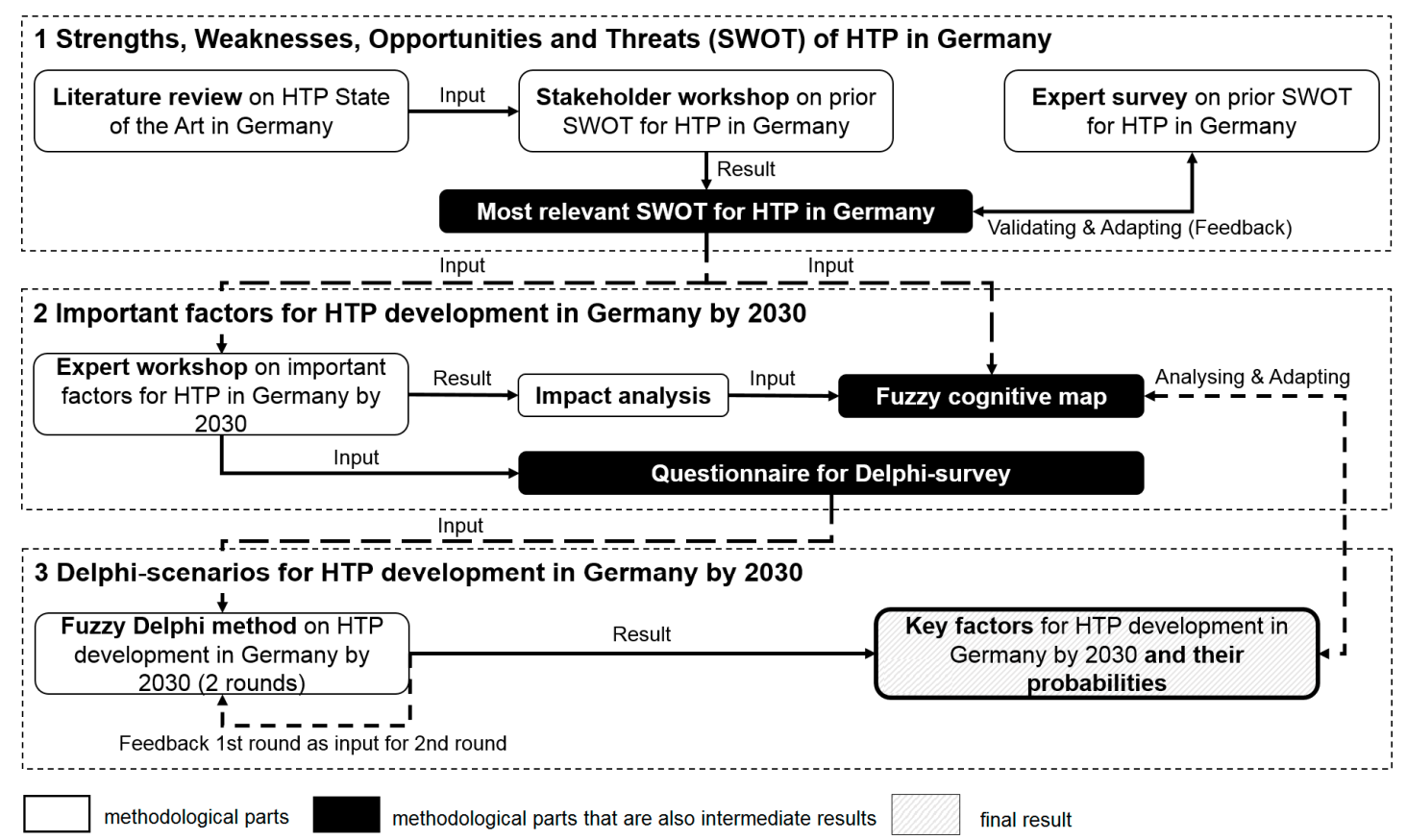

Figure 1. Study design.

The methodological framework is, in part, similar to the Hybrid Delphi method [45]. However, it also includes further methodological elements (literature review, impact analysis, fuzzy logic). Based on a comprehensive literature study [4], a moderated focus group workshop on the success and risk factors of HTP development in Germany was carried out. The results were validated and underpinned by a subsequent expert survey. A total of 41 experts, primarily scientists, plant manufacturers and plant operators from Germany and Switzerland, participated in the workshop. The expert survey panel consisted of feedstock suppliers, technology developers, technology users, retailers, product users, policy makers, and researchers from Germany. Within the workshop, the experts were asked about certain success and risk factors for HTP in Germany that were then collected, categorized, and discussed. In a subsequent expert survey, the results of the workshop were further validated by asking about the strengths, weaknesses, opportunities, and threats for HTP development in Germany. For the detailed procedure and the results of the SWOT analysis, see [36]. 
Based on these initial findings, a "long list" of important factors of HTP future development, their relationships, and interactions was derived through an expert scenario workshop. Six HTP researchers from the German Biomass Research Centre (DBFZ) participated. The influence analysis performed in this step served as the basis for the development of a Fuzzy-logic Cognitive Map (FCM), which provides an overview of all identified factors/concepts and their relationships. To construct the FCM, however, further expert feedback from the surveys and information from the literature review were included. In this analysis, we used multiple-valued logic scalar numbers from the discrete set $\{-1 ;-0.5 ; 0 ;+0.5 ;+1\}$ to determine the impact relations (arcs and edges) between FCM nodes (concepts). The open source web-based application Mental Modeler was used to create the FCM and identify the factors/concepts importance and connectedness [46].

Based on the results of the expert workshop and the FCM, a questionnaire for a Delphi survey was compiled and sent to 51 HTP experts via an online survey. The FCM factors/concepts (Appendix A, Table A1) served as essential inputs for the preparation of the Delphi questionnaire. However, the use of too many survey items makes cognitive assessments more difficult and thus tends to reduce the reliability of the results, which is why it was decided to integrate particularly factors/concepts with a high FCM centrality (cf. Table 1) into the survey. Nevertheless, following feedback received during the first round of interviews, several items were added to the second questionnaire.

The survey participants were selected based on their expertise. Selection criteria were as follows: (1) academic or professional recommendations, (2) well-known authors of relevant publications on the specific subject, (3) stakeholder group representative, and (4) estimated professional experience within the working field. These criteria were selected based on the suggestion by Stevenson [47] and Hasson et al. [48] to mainly include experts in the field of study (indicated through criteria 1,2 and 4) as well as different stakeholders (criterion 3). The international participants were asked about developments of HTP in the European context, since they were assumed to have, at best, limited knowledge on the German situation. However, both the German and the European situations are comparable. Figure 2 gives an overview of the composition of the participants, their expertise, and the nations represented in the first round of interviews. The relative distribution in the second round of the survey $(n=12)$ was very similar.

Two rounds were conducted in this study. Twenty-seven experts participated in the first round (response rate 1st round: 53\%). Of these 27 people, twelve participated in the second round (response rate 2 nd round: $44 \%$ ). The following item-categories were part of the survey (assessment scales are explained in the Appendix B, Table A2): (1) relevance of factors for HTP development in Germany by 2030, (2) relevance of risks for HTP development in Germany by 2030, (3) estimated probabilities of factor occurrence by 2030 and (4) certainty in assessing per item-category.

Besides evaluating with scales, the experts had the opportunity to explain their selection and assessment in text fields. For both rounds, 22 comments on capacity development, five comments on success factors, four notices regarding risks, and eleven notes on the development of biomass utilization rates were provided. By means of qualitative content analysis (i.e., differentiation between pros and cons, frequencies of keywords, identification of consensus statements) essential statements were summarized (Appendix C, Table A3). The hints of the first round were also included in the preparation of the questionnaire for the second round. 


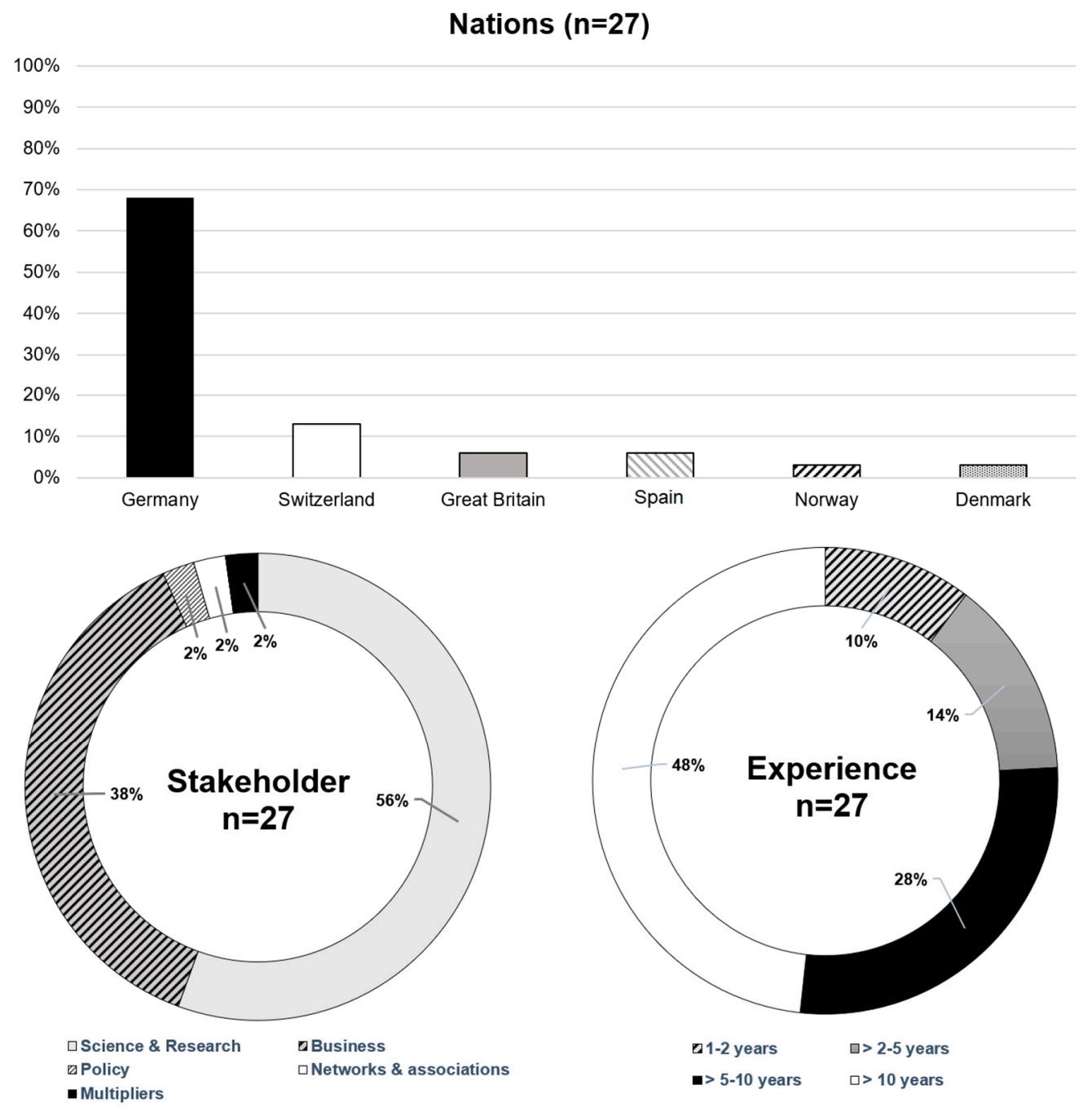

Figure 2. Participants of the first Delphi-survey round.

After the first round, an interim evaluation took place, which showed the degree of agreement in the expert assessments and the frequency of distributions of the first tendencies by descriptive statistics (median, standard deviation, interquartile range (IQR)). The questionnaire for the second round of the survey was adjusted, taking into account the results from round 1. After executing the Delphi survey, we analyzed the results by using the FDM which consists of the following steps [49]:

1. Determining experts (see previous explanations).

2. Selecting a linguistic scale to be converted into a fuzzy-scale (cf. Appendix B, Table A2).

3. Calculating the difference between the average fuzzy number $(m)$ and each experts' fuzzy number (n) per item by using following formula:

$$
d(\widetilde{m}, \widetilde{n})=\sqrt{\frac{1}{3}\left[(m 1-n 1)^{2}+(m 2-n 2)^{2}+(m 3-n 3)^{2}\right]}
$$

4. Determining the threshold value for consensus/dissent of the expert panel:

In accordance with [38], we chose a threshold of $d \leq 0.2$ to make a decision as to whether the experts had reached consensus on the item. Next to this, the frequency of expert agreement is presented as the percentage of $d \leq 0.2$ per item-category in relation to all items. A value of $\leq 75 \%$ represents panel consensus. 


\section{Defuzzification:}

To determine a ranking of the most relevant/probable factors per item-category, it is necessary to defuzzify the fuzzy values into a crisp-value $\left(A_{i}\right)$. For this, we used the following formula in accordance with [38]:

$$
A_{i}=\frac{1}{3}(m 1+m 2+m 3)
$$

\section{Results}

\subsection{Factors for HTP Development in Germany by 2030 and Their Relations}

The development factors and risks were primarily derived on the basis of the expert workshop and the aforementioned previous SWOT analysis executed by the authors [36]. Above all, the expert workshop served as the basis for identifying areas of interest. The factors were then further differentiated and backed up with information from the literature. The whole list of factors is part of the appendix (Table A1).

The factors were assessed in the expert scenario workshop by means of an impact matrix with regard to their mutual influences. Based on this, a Fuzzy-logic Cognitive Map (FCM) was constructed. Figure 3 shows a part of the overall FCM for the relationships of the factor "Regular Fuel Recognition".

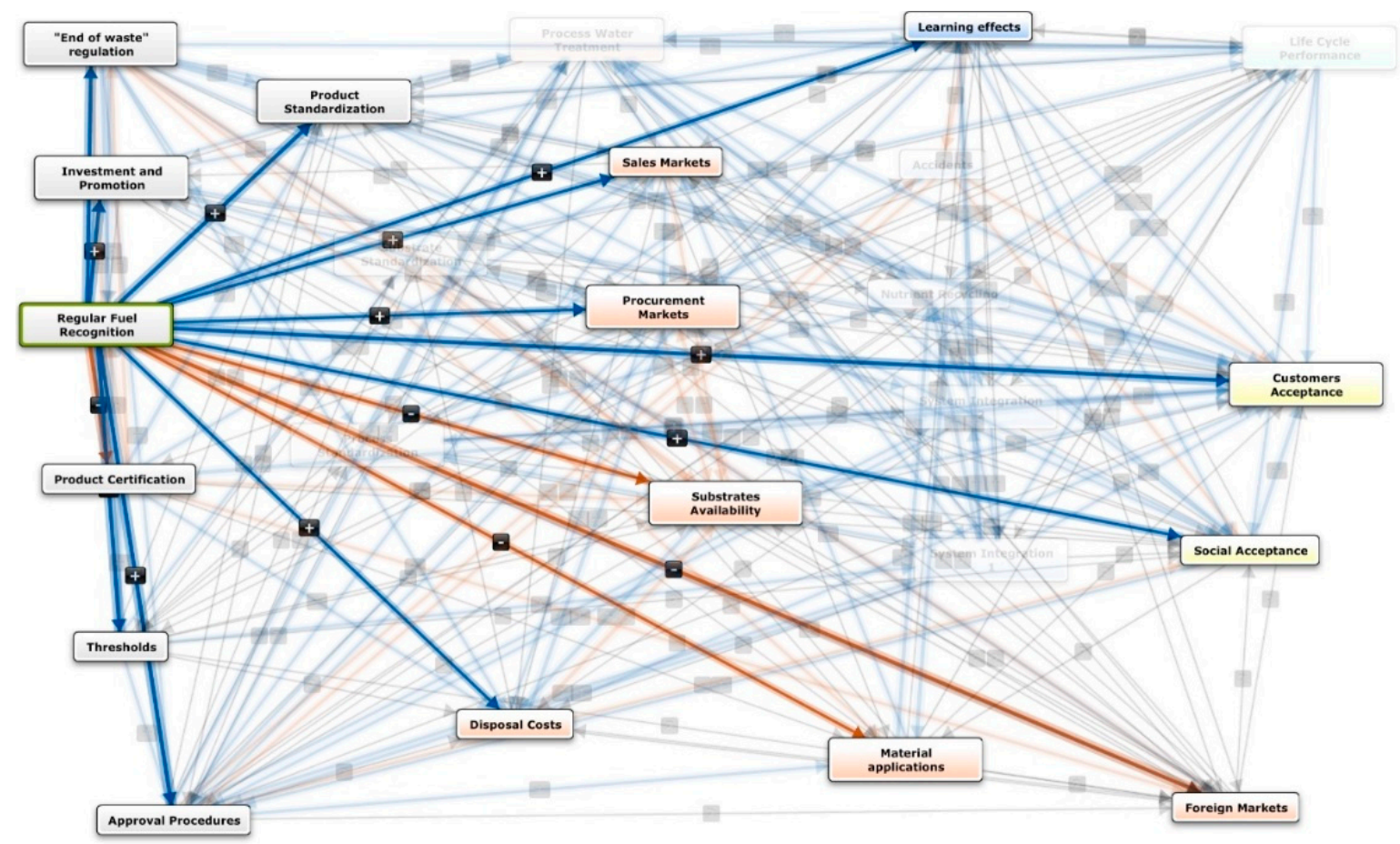

Figure 3. Part of the Fuzzy-logic Cognitive Map (FCM) for the impact of the concept "Regular Fuel Recognition" on other system concepts (expert knowledge-based FCM created with the Mental Modeler).

Since FCM is based on graph theory, which provides a wide variety of indices, we can also make statements about the structure of the system as well as gain information about the functions of individual factors. Table 1 lists the most relevant metrics for the developed FCM including a short definition of the indices. 
Table 1. FCM indices and their scores in the hydrothermal processes (HTP) model.

\begin{tabular}{|c|c|c|}
\hline FCM Indices & Explanation & Indices in HTP Model \\
\hline $\mathrm{N}$ (concepts) & Indicates the total number of system factors $[50,51]$. & 24 \\
\hline $\mathrm{N}$ (connections) & Indicates the total number of connections between the system concepts $[50,51]$. & 235 \\
\hline $\mathrm{N}$ (transmitters) & $\begin{array}{l}\text { Indicates the total number of concepts that influence other concepts but are not } \\
\text { affected by other concepts }[50,52] .\end{array}$ & 0 \\
\hline $\mathrm{N}$ (receiver) & $\begin{array}{l}\text { Indicates the total number of concepts that are influenced by other concepts but } \\
\text { have no effect on them }[50,52] \text {. }\end{array}$ & 1 \\
\hline $\mathrm{N}$ (ordinary) & $\begin{array}{l}\text { Indicates the total number of concepts that affect and are affected by other } \\
\text { concepts }[50,52] .\end{array}$ & 23 \\
\hline Density & $\begin{array}{l}\text { This index shows the networking degree of the system, i.e., the number of } \\
\text { concepts and edge relations. A high density indicates that several probable } \\
\text { management options exist [50,52]. The density can have a value between } 0 \text { and } 1 .\end{array}$ & 0.43 \\
\hline $\mathrm{C} / \mathrm{N}$ & $\begin{array}{l}\text { The number of connections divided by the number of concepts. A low } \mathrm{C} / \mathrm{N} \\
\text { score indicates a high degree of system connectedness [50,51]. Low is relative in } \\
\text { this context, because it must be seen in context with other comparable systems. }\end{array}$ & 9.79 \\
\hline \multirow[b]{2}{*}{ Outdegree \& Indegree } & \multirow{2}{*}{$\begin{array}{l}\text { Information about the concept degree as a transmitter (driver), receiver (output), } \\
\text { or force that conveys effects (ordinary) [53]. }\end{array}$} & $\begin{array}{l}\text { Highest Outdegree (highest driving } \\
\text { force): Regular Fuel Recognition (11.5) }\end{array}$ \\
\hline & & $\begin{array}{l}\text { Highest Indegree (highest receiving } \\
\text { force): Customer Acceptance (10) }\end{array}$ \\
\hline Centrality & Indicates how strongly a concept influences the whole system $[53,54]$. & $\begin{array}{l}\text { Highest Centrality: Regular Fuel } \\
\text { Recognition (13.5) }\end{array}$ \\
\hline Complexity & $\begin{array}{l}\text { Illustrates the degree of model accuracy and measures the degree to which } \\
\text { outcomes of driving forces are considered }[50,51] .\end{array}$ & Infinite \\
\hline
\end{tabular}




\subsection{Results of the Fuzzy-Delphi Method}

Table 2 summarizes the results of consensus or dissent after the second round. For this purpose, the determined fuzzy values $(d)$ are given, where $d \leq 0.2$ is the threshold value. Grey shaded values are the factors where consensus was reached. In addition, the percentage of expert consensus is specified. This indicates how many item evaluations of the entire panel in relation to the total items did not exceed the threshold. Here, a value of at least $75 \%$ is the consensus criterion.

Table 2. Results on the fuzzy evaluation regarding expert consensus/dissent after round 2.

\begin{tabular}{|c|c|c|c|c|}
\hline \multirow[t]{2}{*}{ No. } & \multirow[t]{2}{*}{ Thematic Category } & \multicolumn{3}{|c|}{ Consensus/Dissent after Round $2(n=12)$} \\
\hline & & $d_{\text {factor }}$ & $d_{\text {risk }}$ & $d_{\text {probability }}$ \\
\hline \multicolumn{5}{|c|}{ Political-legal factors } \\
\hline 1 & Regular fuel recognition & 0.178 & 0.183 & 0.204 \\
\hline 2 & Investment and promotion & 0.277 & 0.241 & 0.136 \\
\hline 3 & "End of waste" regulation & 0.170 & 0.221 & 0.263 \\
\hline 4 & Product certification & 0.153 & 0.221 & 0.164 \\
\hline 5 & Thresholds & 0.300 & 0.239 & 0.288 \\
\hline 6 & Approval procedures & 0.267 & 0.239 & 0.236 \\
\hline 7 & Product standardization & 0.204 & 0.170 & 0.136 \\
\hline 8 & Substrate standardization & 0.159 & - & 0.192 \\
\hline 9 & Process standardization & 0.083 & 0.265 & 0.213 \\
\hline \multicolumn{5}{|c|}{ Economic factors } \\
\hline 10 & Sales markets & 0.187 & 0.085 & 0.181 \\
\hline 11 & Procurement markets & 0.209 & 0.170 & - \\
\hline 12 & Substrate availability & 0.187 & 0.186 & 0.166 \\
\hline 13 & Disposal costs & 0.209 & 0.293 & 0.199 \\
\hline 14 & Material applications & 0.226 & - & 0.235 \\
\hline 15 & Foreign markets & - & 0.208 & - \\
\hline \multicolumn{5}{|c|}{ Technological factors } \\
\hline 16 & Process water treatment & 0.170 & 0.204 & 0.136 \\
\hline 17 & System integration 1 & 0.115 & - & 0.162 \\
\hline 18 & System integration 2 & 0.229 & - & 0.187 \\
\hline 19 & Nutrient recycling & 0.178 & - & 0.236 \\
\hline 20 & Learning effects & 0.200 & 0.140 & 0.200 \\
\hline 21 & Accidents & - & 0.265 & - \\
\hline \multicolumn{5}{|c|}{ Ecological factor } \\
\hline 22 & Life cycle performance & 0.378 & - & - \\
\hline Mean & & 0.207 & 0.205 & 0.193 \\
\hline Percen & e of expert consensus & $72 \%$ & $71 \%$ & $76 \%$ \\
\hline
\end{tabular}

Table 2 shows that after the second survey round, majority consensus was achieved in at least one item-category (factors, risks, probabilities). However, for thresholds, approval procedures, material applications, foreign markets, accidents, and life cycle performance, no consensus was reached at all. The panel consensus (last row of Table 2$)$ was not reached regarding factors and risks $(<75 \%)$, which likely shows that the expert assessments tended to be furthest apart for these item-categories.

However, compared to the first round, the second round showed a significant increase in expert consensus. The expert consensus rate increased by 28 percentage points in the assessment of the relevance of the factors, by 19 percentage points in the assessment of the relevance of the risks, and even, by 33 percentage points in the probability of occurrence estimates between the rounds. For some items, there were considerable differences. In particular, the relevance of process standards showed a very strong difference between rounds 1 and $2\left(\Delta d_{\text {factor }}=-80 \%\right)$. This could be due to the fact that in the second round, experts who regard process standards as equally relevant in particular were still involved. This reveals one of the weaknesses of the Delphi method, as there is sometimes a high drop-out rate (in this case $56 \%$ ) between the rounds that can cause changes in the results due to 
differences in the survey panel, rather than solely due to adjustments based on the previous round's results. However, one basic assumption of the Delphi method is that expert consensus increases due to the adaption of evaluation based on the previous round's results, which is why we basically also assumed this for the consensus increase in this study. For the factors/concepts in which a consensus was reached (grey shaded in Table 2), Table 3 shows the values $\left(A_{i}\right)$ after defuzzification. Based on this, the items' fuzzy logic-based relevance/probability can be ranked. Factors/concepts that are not greyed out in Table 3 were no longer considered in the corresponding categories, as a dissent prevailed in the expert assessments. We differentiated between:

- $\quad A_{f}=$ defuzzified value for factors

- $A_{r}=$ defuzzified value for risks

- $A_{p}=$ defuzzified value for probabilities

- $A_{c}=$ defuzzified value for certainty in assessment

- $\quad \operatorname{Rank}_{f}=$ Rank in relation to other factors

- $\quad R_{a n k}=$ Rank in relation to other risks

- $R a n k_{p}=$ Rank in relation to other probabilities

Table 3. Ranking of consensus items in terms of relevance and probabilities after defuzzification.

\begin{tabular}{|c|c|c|c|c|c|c|c|}
\hline No. & $\begin{array}{l}\text { Factors with Consensus in at Least One } \\
\text { Item-Category }\end{array}$ & $A_{f}$ & $\operatorname{Rank}_{f}$ & $A_{r}$ & $\operatorname{Rank}_{r}$ & $A_{p}$ & $\operatorname{Rank}_{p}$ \\
\hline \multicolumn{8}{|c|}{ Political-legal factors } \\
\hline 1 & Regular fuel recognition & 8.2 & 3 & 5.8 & 2 & n.c. & n.c. \\
\hline 2 & Investment and promotion & n.c. & n.c. & n.c. & n.c. & 2.9 & 9 \\
\hline 3 & "End of waste" regulation & 8.6 & 2 & n.c. & n.c. & n.c. & n.c. \\
\hline 4 & Product certification & 7.4 & 5 & n.c. & n.c. & 3.8 & 8 \\
\hline 7 & Product standardization & n.c. & n.c. & 5.6 & 3 & 3.9 & 7 \\
\hline 8 & Substrate standardization & 2.6 & 10 & - & - & 2.0 & 10 \\
\hline 9 & Process standardization & 2.8 & 9 & n.c. & n.c. & n.c. & n.c. \\
\hline \multicolumn{8}{|c|}{ Economic factors } \\
\hline 10 & Sales markets & 4.6 & 8 & 2.8 & 5 & 6.1 & 4 \\
\hline 11 & Procurement markets & n.c. & n.c. & 4.4 & 4 & - & - \\
\hline 12 & Substrate availability & 5.0 & 7 & 2.8 & 5 & 6.8 & 1 \\
\hline 13 & Disposal costs & n.c. & n.c. & n.c. & n.c. & 6.2 & 3 \\
\hline \multicolumn{8}{|c|}{ Technological factors } \\
\hline 16 & Process water treatment & 8.0 & 4 & n.c. & n.c. & 6.8 & 1 \\
\hline 17 & System integration 1 & 9.0 & 1 & - & - & 6.0 & 5 \\
\hline 18 & System integration 2 & n.c. & n.c. & - & - & 4.6 & 6 \\
\hline 19 & Nutrient recycling & 8.2 & 3 & - & - & n.c. & n.c. \\
\hline 20 & Learning effects & 6.4 & 6 & 7.4 & 1 & 6.4 & 2 \\
\hline \multicolumn{2}{|c|}{$\begin{array}{l}\text { Certainty in the assessment of the item category } \\
\text { according to the experts' own statements: } A_{c}\end{array}$} & \multicolumn{2}{|c|}{6.4} & \multicolumn{2}{|c|}{5.6} & \multicolumn{2}{|c|}{5.0} \\
\hline
\end{tabular}

"n.c." = no consensus reached; "-" = factor was not part of this item-category.

Table 3 shows that the assessments of the relevance of occurrence of a factor $\left(A_{f}\right)$ and the risk of non-occurrence $\left(A_{r}\right)$ are very different. For example, the absence of learning effects (e.g., lack of reference facilities) is considered to be a significant risk (7.4). However, the relevance of this factor is also still high (6.4) but only in the midfield relative to other factors. The uncertainty according to the panelists' own assessments $\left(A_{c}\right)$ is highest in the probabilities and lowest in the relevance of the factors. However, the values are close to each other, which is why the assessment certainty of the item categories is largely the same.

Regarding the relationships between mutually relevant factors and corresponding probabilities (grey shaded in Table 3), only a few factors show high values (i.e., near to 10) for both. Figure 4 visualizes the relationships. 


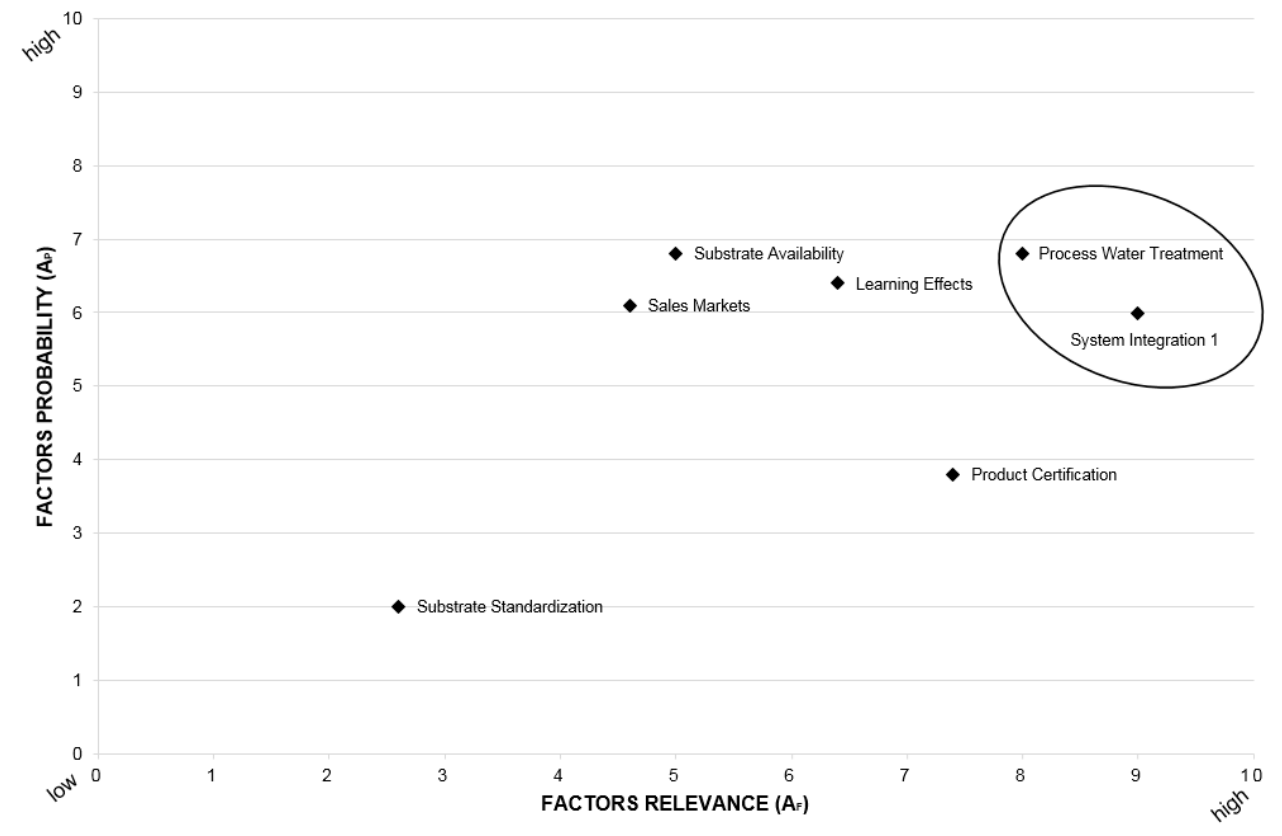

Figure 4. Combination of relevance and probability of consensus factors after defuzzification.

Only two factors were considered to be highly relevant and also highly probable. Namely, the introduction of a cost-effective process water treatment and the integration of HTP into existing bio-waste and wastewater treatment plants.

\section{Discussion}

Although HTP has already been shown to have an advantage on some points (e.g., HHV, energy yields, decreasing specific investment costs while increasing capacity), the analysis showed that there are several factors related to the development of HTP in Germany that have hindered successful development so far. Above all, political-legal aspects are strongly inhibiting a scale-up in Germany, but adaptions in the near future are considered unlikely. This shows that the experts involved think that the legislator or the political decision-makers have relatively little ambition to promote the development of HTP more strongly. This is already evident today as some German HTP plant manufacturers and operators are already focusing on foreign markets (especially China). Nevertheless, HTP could considerably contribute to the achievement of a bio-based economy by efficiently converting currently difficult-to-use wet biomasses into valuable products. However, the adaptation of the legal framework is urgently needed for this. If the national legislator does not take action, an important step could also be the development of an EU regulation on the end-of-waste status of waste biomass products, similar to those already introduced for scrap iron, scrap steel, and scrap aluminum as well as for certain types of glass. One of the reasons for this is that the legal uncertainty for plant operators and product users is very high, which, in turn, increases transaction costs [55]. Due to the fact that HTP products cannot be used as standard fuels, the energy market cannot be fully penetrated, which significantly reduces the product's market potential. However, there are still many problems at the technological level. So far, Germany is still a technology leader in the field of HTP (e.g., as indicated through patents) [19]. Based on results of this analysis, it is politically recommendable to work actively on measures that ensure that HTP are used economically in Germany and do not become exclusively an export product as this could cause related companies to relocate their headquarters abroad.

In addition, technological advancements are considered to be relevant drivers and are also estimated to be relatively likely. Above all, a mature technology for the cost-effective treatment of the process water is urgently needed to reduce the overall related costs and thus increase the cost-effectiveness of the process. In addition, an efficient treatment process for polluted water is also needed to aid in 
environmental protection. Potential for promoting the development of HTP is seen particularly in system integration, for example, into existing bio-waste and waste-water treatment plants (WWTP). The resulting synergies can, in particular, save logistics costs and directly link the locations of substrate occurrence, conversion technology and, in some cases, customers. The experts probably regard technological advances as likely because corresponding research and development is very active. In particular, cost-effective solutions for the process water treatment are being intensively researched [56-58], which is why suitable solutions are likely to be expected in this area in the foreseeable future. As an overview, Table 4 summarizes the main results of this study, i.e., the most crucial barriers and potential for future HTP development and the spread of technology as well as suggestions for possible measures to reach the potential benefits for HTP and reduce the barriers to achieving these.

Table 4. Consensual key potential benefits and barriers for HTP development in Germany by 2030 and potential measures.

\begin{tabular}{|c|c|}
\hline Key Development Factor(s) & Potential Measure(s) to Reach Potential Benefits or Reduce Barriers \\
\hline \multicolumn{2}{|l|}{ Key potentials } \\
\hline \multicolumn{2}{|l|}{ Political-legal } \\
\hline $\begin{array}{l}\text { An end-of-waste regulation is being } \\
\text { introduced for HTP products (i.e., products } \\
\text { from bio-waste, sewage sludge etc.), and } \\
\text { HTP energetic products (e.g., hydro-coal) } \\
\text { are recognized as standard fuels. }\end{array}$ & $\begin{array}{l}\text { The European or national legislation has to be adjusted accordingly. This means } \\
\text { that a regulation must be introduced that allows the energetic use of products } \\
\text { from waste biomass. Such a regulation could be very similar to regulations } \\
\text { already being introduced for broken glass and steel scrap. }\end{array}$ \\
\hline \multicolumn{2}{|l|}{ Technological } \\
\hline $\begin{array}{l}\text { Integration of HTP into existing bio-waste } \\
\text { treatment plants and waste-water treatment } \\
\text { plants (WWTP) including nutrient recycling }\end{array}$ & $\begin{array}{l}\text { Research on suitable technological solutions for the most efficient integration of } \\
\text { HTP into such plants must be fostered. Concepts from biorefinery research } \\
\text { could possibly be used as a basis for good solutions. However, relevant } \\
\text { stakeholders, especially plant operators, must be closely involved (e.g., } \\
\text { with common workshops) to reduce reservations and develop good concepts } \\
\text { together. An important issue for bio-waste plant operators and WWTP } \\
\text { operators could be nutrient recycling as this would provide an additional } \\
\text { economic product (next to HTP products itself), which is highly demanded } \\
\text { (esp. phosphorus [59]) }\end{array}$ \\
\hline \multicolumn{2}{|l|}{ Key barriers } \\
\hline \multicolumn{2}{|l|}{ Political-legal } \\
\hline $\begin{array}{l}\text { Unambitious politics and obstructive } \\
\text { legislation, i.e., no introduction of "end of } \\
\text { waste" directive or alternative (e.g., product } \\
\text { certification). }\end{array}$ & $\begin{array}{l}\text { Relevant political decision-makers have to be motivated for legislative action. } \\
\text { Scientifically-based policy advise (e.g., Scientific Advisory Boards) could be an } \\
\text { important instrument to motivate decision-makers. To create a suitable } \\
\text { argumentative basis for this, research on the economic and ecological benefits } \\
\text { of HTP is necessary but must also be translated into easily understandable } \\
\text { messages and communicated most efficiently. Next to this, political } \\
\text { decision-makers must be integrated into several activities on HTP to increase } \\
\text { attention on the technology. Best-practice cases (business cases) could also be } \\
\text { useful to show the functioning and advantages of the technology. }\end{array}$ \\
\hline \multicolumn{2}{|l|}{ Technological } \\
\hline $\begin{array}{l}\text { The understanding and knowledge of the } \\
\text { process will not increase considerably } \\
\text { (missing learning effects, for example, } \\
\text { through missing reference } \\
\text { systems/business cases). }\end{array}$ & $\begin{array}{l}\text { To reduce this barrier, investment and promotion activities are especially } \\
\text { important (e.g., by public or private funders and investors). Through this, } \\
\text { larger pilot and demonstration plants can also be developed which may help to } \\
\text { increase the understanding of the processes on larger scales. Such reference } \\
\text { plants are important to give investors an impression of how the technology } \\
\text { works, which, in turn, could generate further investments. Learning effects will } \\
\text { occur if sufficient experience with the operation of larger plants is made. } \\
\text { Business cases can serve as important information basis for new projects. }\end{array}$ \\
\hline
\end{tabular}

As mentioned in the introduction, few studies have focused on this issue so far. However, the results of this study are in line with the findings of the similar ones (e.g., the importance of having an efficient process water treatment procedure and the approval of HTP products from residues and waste as standard fuels) which confirms the high importance of the identified key factors. The novel aspect of this study, however, is that in addition to the relevant literature, extensive expert knowledge was included and evaluated in a structured manner. In addition, this study initially depicted all 
relevant key factors and did not focus on selected aspects directly at the start of the analysis, which is why the methodology can be regarded as non-normative. The application of FCM shows, for the first time, how the individual factors are related. The use of fuzzy logic also takes into account the bias of qualitative assessments (e.g., due to different participants' estimations of "important" and "unimportant"). Although the studies mentioned in the introduction showed very similar results to this analysis, some only considered individual technologies and not the entire technology platform (e.g., [19]) or they focused on very specific contexts (e.g., the contribution of HTC and HTL to the flexibility of a renewable energy system) (e.g., [35]), which is why not all relevant system factors were considered. The aforementioned studies did not prioritize the potential benefits and barriers to HTP development like this analysis, but they also classified them into categories and highlighted the high importance of the already mentioned legal and technological factors. Hence, this study confirms the entirety of the results of the mentioned studies and substantiates them both in terms of content (expert knowledge) and by using an alternative methodology (fuzzy logic).

The applied methodology to derive particularly relevant factors, risks, and probabilities of occurrence is unique in this form. Although other technology assessments have applied the Fuzzy Delphi method [60], Fuzzy-logic Cognitive Mapping [61], or SWOT analysis [62], they did not use such a combination. The advantage of this method is the versatile participation format that greatly increases the objectivity of the results overall, since several correction and feedback loops are part of it. The combination of workshops and surveys within this study makes it possible for both conduction of the discourse (workshops) and collection of anonymized content (Delphi survey) to occur. Although other comparable studies also applied participation as a qualitative methodological element [63], the particular kind of methodological combination used (cf. Figure 1) has not previously been used in the literature. The core of information filtering into relevant and probable factors is the Fuzzy Delphi Method. With a total of 27 experts from different stakeholder groups in the first round, this Delphi survey achieved a high level of representativeness, since there are very few HTP experts in the study area anyway. The number of participants is an extremely important factor in achieving meaningful results, so it is strongly recommended that experts are already mobilized before a study of this type is begun. Through the use of fuzzy logic, it became possible to bypass some disadvantages of the classical Delphi method. In particular, the different types of assessment by people on the basis of linguistic scales can be easily circumvented by fuzzy scales [64]. Another key element of this analysis was the application of the FCM method. Again, fuzzy logic was used to translate qualitative expert assessments into a model that represented the overall system of factors. In this study, the mapping was conducted as part of a workshop with six experts. We preferred a smaller group to ensure discussion and to prevent over-standardization of the workshop. A standardization of the mapping, for example, via online formats or targeted queries, would certainly allow a larger number of participants. The creation of an FCM requires a high level of cognitive performance, but it helps to structure the complexity of a system to identify feedback loops or so-called "hidden patterns". Identification of the dependencies of the factors must be carried out carefully, as this is the central way for the system effect to be identified. Nevertheless, the results are meaningful as a "scoreboard" and do not guarantee objective accuracy, as this is not the aim of a qualitative analysis like this one anyway. Looking into the future always involves high uncertainty and particularly shows ranges and opportunities.

\section{Conclusions}

In this study, we asked for the reasons why HTP does not yet prevail on a large industrial scale in Germany. By means of a literature- and expert knowledge-based fuzzy logic analysis, we identified key factors and prioritized them. The study results show that political and legal adjustments to the relevant framework conditions as well as technological improvements are seen as very important for the positive future development of HTP in Germany. This especially includes the key potential benefits shown in Table 4. These factors are strongly connected to other system components which shows their high impact on the whole system. The results can serve as important information for 
HTP stakeholders in Germany, especially political decision-makers, entrepreneurs, and researchers. However, the limitations of the study are that the findings are only valid for the German situation. Other nations require their own comparative studies. Additionally, the study was highly qualitative in nature due to the insufficient information and data situation in this field of research. Hence, some uncertainty remains which is, nevertheless, very common for analyses that deal with future developments. In the future, the identified factors and interconnections shall serve as a basis for upcoming scenario case studies focusing on the system and plant levels (also, in part, quantitively). In this way, we hope to gain even more insight into desirable technological, economic, ecological, and political-legal developments for HTP by 2030 in Germany.

Author Contributions: Conceptualization, D.R. and A.B.; Data curation, D.R.; Formal analysis, D.R.; Funding acquisition, D.T. and A.B.; Investigation, D.R.; Methodology, D.R.; Project administration, D.T. and A.B.; Software, D.R.; Supervision, D.T. and A.B.; Validation, D.R.; Visualization, D.R.; Writing一original draft, D.R.; Writing-review \& editing, D.R., D.T. and A.B.

Funding: This work was supported by the Helmholtz Association under the Joint Initiative "Energy System 2050-A Contribution of the Research Field Energy".

Acknowledgments: We are grateful to all experts, who have supported us within the various participation formats. Special thanks go to Benjamin Wirth, who helped to organize the expert workshop for the derivation of the impact matrix. Additionally, we want to thank the anonymous reviewers for their valuable and helpful comments and suggestions.

Conflicts of Interest: The authors declare no conflict of interest. The funders had no role in the design of the study; in the collection, analyses, or interpretation of data; in the writing of the manuscript, or in the decision to publish the results.

\section{Appendix A. List of Relevant System Factors for HTP Development in Germany}

The factors are formulated in positive form and thus represent a desired event; the corresponding negative formulation represents a risk. However, the non-occurrence of a factor is not always considered as a risk. In addition, risks were identified that do not necessarily represent a development factor in their inverse effect (accordingly, they are not formulated in positive form). Such factors are marked with asterisks.

Table A1. "Long list" of factors for HTP development in Germany by 2030.

\begin{tabular}{|c|c|c|}
\hline$x_{i}$ & Tagging & Factors/Concepts Explanation \\
\hline \multicolumn{3}{|c|}{ Political-legal factors/concepts } \\
\hline 1 & $\begin{array}{l}\text { Regular fuel } \\
\text { recognition }\end{array}$ & $\begin{array}{l}\text { HTP energetic products (e.g., hydro-coal) are recognized as standard fuels. This factor is } \\
\text { strongly connected to the fourth factor as this represents an alternative requirement for the } \\
\text { recognition of HTP products as standard fuels. }\end{array}$ \\
\hline 2 & $\begin{array}{l}\text { Investment and } \\
\text { promotion }\end{array}$ & $\begin{array}{l}\text { Investment incentives (e.g., policy support instruments) and/or technology and research } \\
\text { funding programs for HTP are being introduced or, rather, promoted. }\end{array}$ \\
\hline 4 & Product certification & $\begin{array}{l}\text { Official recognition certificates for HTP products are introduced and issued accordingly by the } \\
\text { competent authorities. This helps to reduce uncertainty in practice in terms of the classification } \\
\text { of HTP products as fuels. }\end{array}$ \\
\hline 5 & Thresholds & $\begin{array}{l}\text { Thresholds relevant to HTP (e.g., the Federal Immission Control Act) are relaxed as far as } \\
\text { reasonably possible. }\end{array}$ \\
\hline 7 & $\begin{array}{l}\text { Product } \\
\text { standardization }\end{array}$ & $\begin{array}{l}\text { The quality of HTP products is standardized (e.g., fuel standard). This helps to reduce } \\
\text { uncertainties with HTP products and sales markets (e.g., for product users) and enhances } \\
\text { transparency. }\end{array}$ \\
\hline 8 & $\begin{array}{l}\text { Substrate } \\
\text { standardization * }\end{array}$ & $\begin{array}{l}\text { The quality of HTP substrates is standardized (e.g., ISO standard). This helps to reduce } \\
\text { uncertainties with HTP procurement markets (e.g., for substrate users) and } \\
\text { enhances transparency. }\end{array}$ \\
\hline 9 & $\begin{array}{l}\text { Process } \\
\text { standardization }\end{array}$ & $\begin{array}{l}\text { Process standards are introduced (e.g., ISO standard). This helps to reduce uncertainties for } \\
\text { plant constructers and operators and enhances transparency. }\end{array}$ \\
\hline
\end{tabular}


Table A1. Cont.

\begin{tabular}{|c|c|c|}
\hline$x_{i}$ & Tagging & Factors/Concepts Explanation \\
\hline \multicolumn{3}{|c|}{ Economic factors/concepts } \\
\hline 10 & Sales markets & $\begin{array}{l}\text { The competition on HTP relevant sales and product markets (e.g., energy carriers, fertilizers, } \\
\text { substitutes for chemical products) decreases. Thus, the relative market share for HTP firms } \\
\text { might be increased. }\end{array}$ \\
\hline 11 & Procurement markets & $\begin{array}{l}\text { The competition in HTP relevant procurement markets (e.g., animal excreta, sewage sludge) } \\
\text { decreases. Thus, more usable substrates for HTP might be available, possibly near to the plant } \\
\text { location. }\end{array}$ \\
\hline 12 & Substrate availability & $\begin{array}{l}\text { The available and technically usable amount of substrates increases. Thus, in centralized } \\
\text { concepts, plants might be able to handle higher capacities, or in decentralized concepts, more } \\
\text { substrates will be available near to the plant location assuming that substrate availability } \\
\text { increases equally in Germany. }\end{array}$ \\
\hline 13 & Disposal costs & $\begin{array}{l}\text { Disposal costs for HTP substrates per mass unit (e.g., ton) are increasing. Thus, revenue for the } \\
\text { disposal of such substrates might also increase which would generate additional income for } \\
\text { HTP plant operators. }\end{array}$ \\
\hline 14 & Material applications* & $\begin{array}{l}\text { HTP products are primarily used for material applications (e.g., as fertilizer, functional carbon). } \\
\text { This could result if energy markets remain unprofitable due to legal barriers (missing } \\
\text { recognition as regular fuels). Products for HTP might be primary applied in markets for } \\
\text { bio-based products. However, this factor strongly depends on missing legal adjustments } \\
\text { regarding fuel recognition according to experts' opinions. }\end{array}$ \\
\hline 15 & Foreign markets ** & $\begin{array}{l}\text { HTP plant manufacturers and operators concentrate almost exclusively on foreign markets. } \\
\text { This might be a result of missing market demand, an insufficient or rather braking legal } \\
\text { framework, low relative market shares for HTP products in related markets or missing political } \\
\text { incentives and willingness to promote HTP in Germany. }\end{array}$ \\
\hline \multicolumn{3}{|c|}{ Technological factors/concepts } \\
\hline 16 & $\begin{array}{c}\text { Process water } \\
\text { treatment }\end{array}$ & $\begin{array}{l}\text { A cost-efficient and sustainable solution for process water treatment is being developed and } \\
\text { applied nationwide. This might promote the overall economic (and ecological) performance of } \\
\text { HTP as the process water treatment is currently also a relevant cost (economic) factor that might } \\
\text { make HTP concepts uneconomic. }\end{array}$ \\
\hline
\end{tabular}

17 System integration 1 * Thus, the locations of substrate occurrence and treatment facilities could be integrated optimally, leading to lower logistic costs. Also, other synergies might be generated, e.g., process water is treated directly by the wastewater treatment plant on site.

18 System integration 2* HTP are increasingly being integrated into bio-refineries. This could also generate considerable synergies (e.g., cascade usage networks).

synergies (e.g., cascade usage networks).

19 Nutrient recycling * be promising as the process water must be treated anyway. Due to political and legal frameworks (2017 amendment of sewage sludge ordinance) that especially require phosphorus recovery from sewage sludge, this might be a useful strategy.

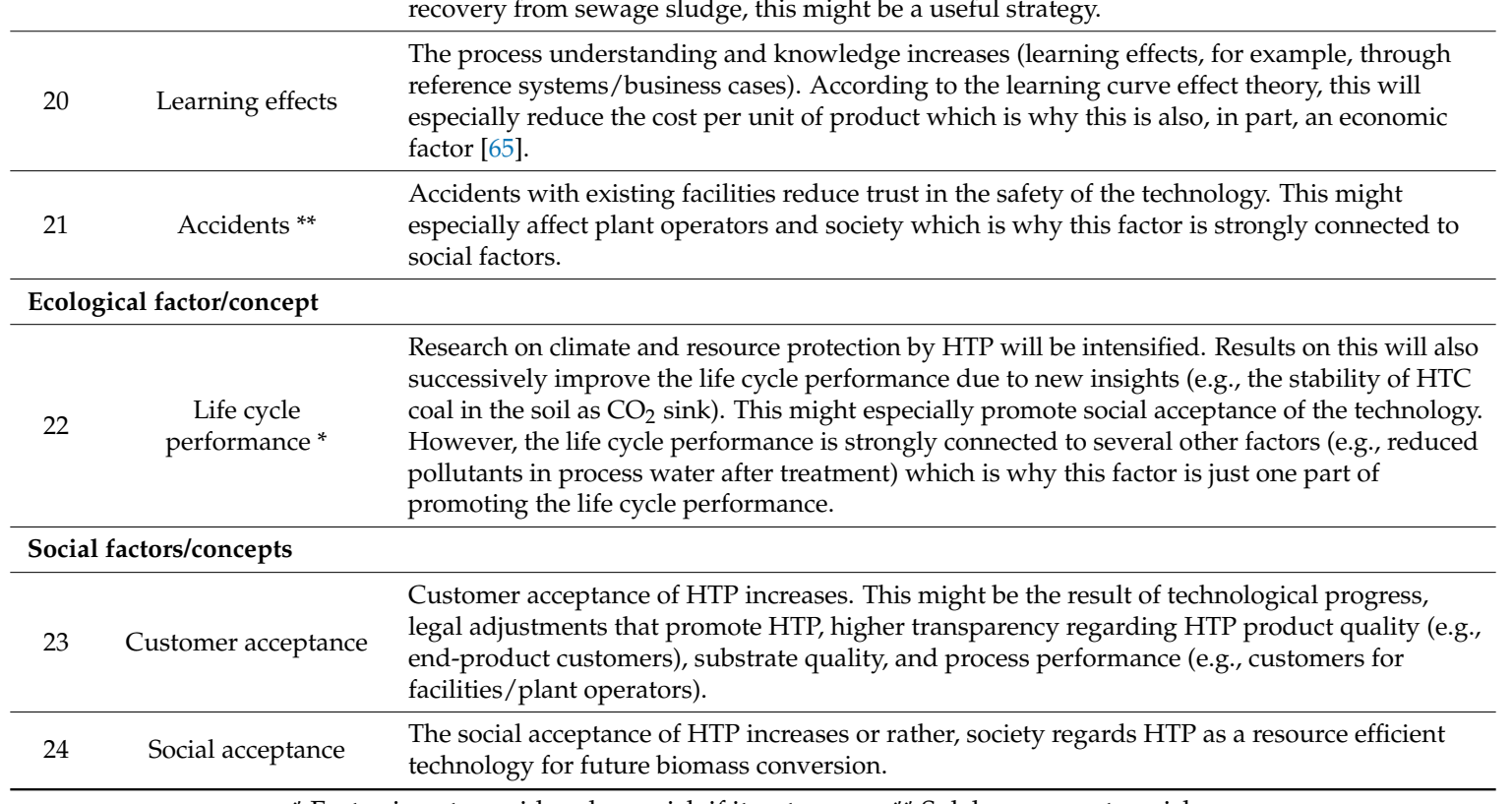

\footnotetext{
${ }^{*}$ Factor is not considered as a risk if it not occurs; ${ }^{* *}$ Solely represents a risk.
} 


\section{Appendix B. Scale Relations}

Table A2. Linguistic variables of Delphi survey item-categories and corresponding Likert and fuzzy scales.

\begin{tabular}{ccccc}
\hline Linguistic Scale & Likert Scale & \multicolumn{3}{c}{ Fuzzy Scale } \\
\hline For item categories "relevance of factors" & and "relevance of risks" \\
\hline extremely relevant & 5 & 0.6 & 0.8 & 1 \\
very relevant & 4 & 0.4 & 0.6 & 0.8 \\
relevant & 3 & 0.2 & 0.4 & 0.6 \\
barely relevant & 2 & 0 & 0.2 & 0.4 \\
irrelevant & 1 & 0 & 0 & 0.2 \\
\hline For item category "probability of factors" & & & \\
\hline very high & 5 & 0.6 & 0.8 & 1 \\
high & 4 & 0.4 & 0.6 & 0.8 \\
middle & 3 & 0.2 & 0.4 & 0.6 \\
low & 2 & 0 & 0.2 & 0.4 \\
very low & 1 & 0 & 0 & 0.2 \\
\hline For item category "assessment (un)certainty" & & \\
\hline very certain & 5 & 0.6 & 0.8 & 1 \\
certain & 4 & 0.4 & 0.6 & 0.8 \\
relative certain & 3 & 0.2 & 0.4 & 0.6 \\
uncertain & 2 & 0 & 0.2 & 0.4 \\
very uncertain & 1 & 0 & 0 & 0.2 \\
\hline
\end{tabular}

\section{Appendix C. Expert Statements in the Delphi Survey}

Table A3. Summarized comments and hint of experts in the Delphi survey.

\begin{tabular}{|c|c|}
\hline Category & Key Statements of the Experts \\
\hline $\begin{array}{l}\text { Arguments for a plant } \\
\text { capacity increase }\end{array}$ & $\begin{array}{l}\text { - } \quad \text { Capacity will increase for plants that currently only exist on a pilot scale. } \\
\text { - } \quad \text { Capacity expansion due to legal adjustments and additional economic } \\
\text { opportunities (e.g., additional revenue from rising carbon allowances due to } \\
\text { an end of waste regulation for bio-coal). } \\
\text { - } \quad \text { Easy scalability of the systems due to modular design. } \\
\text { - } \quad \text { Learning effects, experience, and technological advances (for example, } \\
\text { process water treatment solutions). } \\
\text { - Scale effects and scale advantages. } \\
\text { HTC plants must be based on wastewater treatment plants of the size 3-4, } \\
\text { therefore requiring a capacity of 50,000 metric tons biomass input per year. }\end{array}$ \\
\hline $\begin{array}{l}\text { Arguments against a } \\
\text { plant capacity increase }\end{array}$ & $\begin{array}{l}\text { - For the most relevant fields of HTP application (mainly the disposal sector), } \\
\text { the current capacity is sufficient. } \\
\text { - For wet biomass, only relatively small amounts are meaningful for ecologic } \\
\left(\mathrm{CO}_{2}\right) \text { and economic (costs) transport, which limits the capacity. } \\
\text { - The plants are used decentral, because substrate availability is crucial. That } \\
\text { limits the capacity. }\end{array}$ \\
\hline $\begin{array}{l}\text { Notes on relevant } \\
\text { success factors }\end{array}$ & $\begin{array}{l}\text { - } \quad \text { HTP must be evaluated holistically to show its potential benefits. } \\
\text { - } \quad \text { Regulatory and political measures need to be implemented. }\end{array}$ \\
\hline $\begin{array}{l}\text { Notes on relevant risk } \\
\text { factors }\end{array}$ & $\begin{array}{l}\text { - Today's expectations of the technology will be not fulfilled (especially } \\
\text { economically and ecologically). } \\
\text { - The environmental effects are misjudged. } \\
\text { - The pressure of competition is increasing. }\end{array}$ \\
\hline
\end{tabular}


Table A3. Cont.

\begin{tabular}{lll}
\hline Category & Key Statements of the Experts \\
\hline $\begin{array}{l}\text { Arguments for an } \\
\text { increase in the biomass } \\
\text { utilization rate }\end{array}$ & - & $\begin{array}{l}\text { Environmental benefits compared to landfilling and anaerobic digestion } \\
\text { promote HTP deployment, but it has to be backed by legislation } \\
\text { and incentives. }\end{array}$ \\
\hline $\begin{array}{l}\text { Arguments against an } \\
\text { increase in the biomass } \\
\text { utilization rate }\end{array}$ & - & Growing environmental awareness. \\
\hline
\end{tabular}

\section{References}

1. German Federal Government. Deutsche Nachhaltigkeitsstrategie, Neuauflage 2016; German Federal Government: Berlin, Germany, 2016; pp. 35-40.

2. Searle, S.; Malins, C. National Case Studies on Potential Waste and Residue Availability for Cellulosic Biofuel Production in the EU. The International Council on Clean Transportation, 2015. Available online: http:/ / www.theicct.org/sites/default/files/ICCT_EU-national-wastes-residues_Feb2015.pdf (accessed on 6 October 2018).

3. Brosowski, A.; Thrän, D.; Mantau, U.; Mahro, B.; Erdmann, G.; Adler, P.; Stinner, W.; Reinhold, G.; Hering, T.; Blanke, C. A review of biomass potential and current utilisation-Status Quo for 93 biogenic waste and residues in Germany. Biomass Bioenergy 2016, 95, 257-272. [CrossRef]

4. Reißmann, D.; Thrän, D.; Bezama, A. Hydrothermal Processes as treatment paths for biogenic residues in Germany: A review of the technology, sustainability and legal aspects. J. Clean. Prod. 2018, 172, 239-252. [CrossRef]

5. German Federal Ministry of Food and Agriculture. National Policy Strategy on Bioeconomy. Renewable Resources and Biotechnological Processes as a Basis for Food, Industry and Energy. Division 531-Strategy and Coordination of the Directorate-General 'Biobased Business, Sustainable Agriculture and Forestry'; German Federal Ministry of Food and Agriculture: Berlin, Germany, 2014.

6. European Commission. Innovating for Sustainable Growth: A Bioeconomy for Europe; Communication COM(2012) 60 Final; European Commission: Brussels, Belgium, 2012.

7. Bezama, A. Let us discuss how cascading can help implement the circular economy and the bio-economy strategies. Waste Manag. Res. 2016, 34, 593-594. [CrossRef] [PubMed]

8. Hildebrandt, J.; O'Keeffe, S.; Bezama, A.; Thrän, D. Revealing the environmental advantages of industrial symbiosis in wood-based bioeconomy networks-An assessment from a life cycle perspective. J. Ind. Ecol. 2018. [CrossRef]

9. Kruse, A.; Funke, A.; Titrici, M.M. Hydrothermal conversion of biomass to fuels and energetic materials. Curr. Opin. Chem. Biol. 2013, 17, 515-521. [CrossRef] [PubMed]

10. Libra, J.A.; Ro, K.S.; Kammann, C.; Funke, A.; Berge, N.; Neubauer, Y.; Titrici, M.M.; Fühner, C.; Bens, O.; Kern, J.; Emmerich, K.H. Hydrothermal carbonization of biomass residuals: A comparative review of the chemistry, processes and applications of wet and dry pyrolysis. Biofuels 2011, 2, 89-124. [CrossRef]

11. Greve, T.; Neudeck, D.; Rebling, T.; Röhrdanz, M. Prospects for the sustainable utilization of organic waste by Hydrothermal Carbonization. Müll Abfall 2014, 2, 86-93. Available online: https:/ /www.muellundabfall. de/MA.02.2014.086 (accessed on 8 October 2018). (In German)

12. Fiori, L.; Lucian, M. Hydrothermal Carbonization of Waste Biomass: Process Design, Modeling, Energy Efficiency and Cost Analysis. Energies 2017, 10, 211. [CrossRef]

13. Lu, X.; Jordan, B.; Berge, N.D. Thermal conversion of municipal solid waste via hydrothermal carbonization: Comparison of carbonization products to products from current waste management techniques. Waste Manag. 2012, 32, 1353-1365. [CrossRef]

14. Zhang, Y. Hydrothermal Liquefaction to Convert Biomass into Crude Oil. In Biofuels from Agricultural Wastes and Byproducts; Hans, P., Blaschek, H.P., Ezeji, T.C., Scheffran, J., Eds.; Wiley-Blackwell: Hoboken, NJ, USA, 2010; pp. 201-232. ISBN 978-0-813-80252-7.

15. Kruse, A. Hydrothermal biomass gasification. J. Supercrit. Fluids 2009, 47, 391-399. [CrossRef] 
16. Pala, M.; Kantarli, I.C.; Buyukisik, H.B.; Yanik, J. Hydrothermal carbonization and torrefaction of grape pomace: A comparative evaluation. Bioresour. Technol. 2014, 161, 255-262. [CrossRef]

17. Berge, N.D.; Flora, J.R.V.; Drive, B.; Carolina, N. Energy Source Creation from Diverted Food Wastes via Hydrothermal Carbonization; Technical Report; Environmental Research and Education Foundation: Raleigh, NC, USA, 2015.

18. Hognon, C.; Delrue, F.; Texier, J.; Grateau, M.; Thiery, S.; Miller, H.; Roubaud, A. Comparison of pyrolysis and hydrothermal liquefaction of Chlamydomonas reinhardtii. Growth studies on the recovered hydrothermal aqueous phase. Biomass Bioenergy 2015, 73, 23-31. [CrossRef]

19. De Mena Pardo, B.; Doyle, L.; Renz, M.; Salimbeni, A. (Eds.) Industrial Scale Hydrothermal Carbonization: New Applications for Wet Biomass Waste; ttz Bremerhaven: Bremerhaven, Germany, 2016; ISBN 978-3-00-052950-4.

20. Kruse, A.; Dahmen, N. Hydrothermal biomass conversion-Quo vadis? J. Supercrit. Fluids 2018, 134, 114-123. [CrossRef]

21. Elliott, D.C.; Hart, T.R.; Neuenschwander, G.G.; Rotness, L.J.; Olarte, M.V.; Zacher, A.V. Chemical Processing in High-Pressure Aqueous Environments. 9. Process Development for Catalytic Gasification of Algae Feedstocks. Ind. Eng. Chem. Res. 2012, 51, 10768-11077. [CrossRef]

22. Elliot, D.C.; Neuenschwander, G.G.; Hart, T.R.; Rotness, L.J.; Zacher, A.H.; Santosa, T.M.; Valkenburg, C.; Jones, S.B.; Tjokro Rahardjo, S.A. Catalytic Hydrothermal Gasification of Lignin-Rich Biorefinery Residues and Algae; Final Report; Pacific Northwest National Laboratory: Richland, WA, USA, 2009.

23. Jones, S.; Zhu, Y.; Anderson, D.; Hallen, R.; Elliot, D.; Schmidt, A.; Albrecht, K.; Hart, T.; Butcher, M.; Drennan, C.; et al. Process Design and Economics for the Conversion of Algal Biomass to Hydrocarbons: Whole Algae Hydrothermal Liquefaction and Upgrading; Pacific Northwest National Laboratory: Richland, WA, USA, 2014.

24. TerraNova Energy GmbH. Projekt Jining: TerraNova Ultra Anlage für 40.000 Jahrestonnen Klärschlamm. Available online: http://terranova-energy.com/blog/project/projekt-compiegne/ (accessed on 29 November 2018).

25. The Ingelia Patented HTC Plant. Available online: https://ingelia.com/index.php/modelo-negocio/ carbonizacion-de-biomasa/?lang=en (accessed on 10 October 2018).

26. REVATECH Produkte Blue Coal. Available online: http://revatec.de/bluecoal.htm (accessed on 8 October 2018).

27. Klemm, M. Hydrothermale Carbonisierung (HTC) als Möglichkeit zur Klärschlammnutzung und Phosphorrückgewinnung. Presentation, 2016. Available online: http://www.thermolyphos.de/wp-content/ uploads/2016/11/1-8-Klemm_161004_Hydrothermal.pdf (accessed on 8 October 2018).

28. Siemon, D.; HTC-Verfahren für Grünabfälle der SunCoal Industries. Berlin, Germany. Presentation, 2013. Available online: https://www.kompetenz-wasser.de/wp-content/uploads/2017/05/htc-4-von_ploetz.pdf (accessed on 08 October 2018). (In German)

29. TerraNova Energy. Clean Energy beyond Coal: Energiebilanz TerraNova Energy Verfahren. Presentation, 2011. Available online: https:/ / www.landwirtschaftskammer.de/duesse/znr/pdfs/2011/2011-06-30-htc05.pdf (accessed on 8 October 2018).

30. Umweltbundesamt (UBA) (Ed.) Chancen und Risiken des Einsatzes von Biokohle und Anderer "Veränderter" Biomasse als Bodenhilfsstoffe oder für die C-Sequestrierung in Böden; Umweltbundesamt: Dessau-Roßlau, Germany, 2016; p. 13ff.

31. Child, M. Industrial-Scale Hydrothermal Carbonization of Waste Sludge Materials for Fuel Production. Master Thesis, Lappeenranta University of Technology, Lappeenranta, Finland, 4 June 2014.

32. AVA-CO2. Klärschlamm Nutzen-Energie Gewinnen: Hydrothermale Carbonisierung. Available online: https:/ / compa.pure-bw.de/sites/default/files/co_pdf_downloads/ava-co2_broschuere_de.pdf (accessed on 8 October 2018).

33. TerraNova Energy. Biokohle aus Reststoffbiomasse und Klärschlamm durch Hydrothermale Karbonisierung (HTC). Presentation, 2011. Available online: http:/ / www.fh-meschede.de/einrichtungen/energietag/2011/ pdf/Hydrothermale_Karbonisierung.pdf (accessed on 8 October 2018).

34. Sammeck, J. Wirtschaftlichkeit und Einsatzstoffe für HTC-Anlagen-erste Erfahrungen. Presentation, 2014. Available online: https:/ / docplayer.org/8461905-Wirtschaftlichkeit-und-einsatzstoffe-fuer-htc-anlagenerste-erfahrungen-narotec.html (accessed on 8 October 2018). 
35. Weidner, E.; Elsner, P. (Eds.) Bioenergie: Technologiesteckbriefe zur Analyse "Flexibilitätskonzepte für die Stromversorgung 2050"; Schriftenreihe Energiesysteme der Zukunft: Berlin, Germany; München, Germany, 2016.

36. Reißmann, D.; Thrän, D.; Bezama, A. Techno-economic and environmental suitability criteria of hydrothermal processes for treating biogenic residues: A SWOT analysis approach. J. Clean. Prod. 2018, 200, $293-304$. [CrossRef]

37. Rowe, G.; Wright, G. The Delphi technique as a forecasting tool: Issues and analysis. Int. J. Forecast. 1999, 15, 353-375. [CrossRef]

38. Sackman, H.; Delphi Assessment: Expert Opinion, Forecasting and Group Process. A Report Prepared for United States Air Force Project RAND. Santa Monica, CA, USA. 1974. Available online: https:/ /www.rand. org/content/dam/rand/pubs/reports/2006/R1283.pdf (accessed on 14 September 2018).

39. Azman, H.; Mohd, N.H.F.; Mohd, S.M.H. Application of Fuzzy Delphi Approach Determining Element in Technical Skills among Students towards the Electrical Engineering Industry Needs. Pertanika J. Soc. Sci. Hum. 2017, 25, 1-8.

40. Wu, K.-Y. Applying the Fuzzy Delphi Method to Analyze the Evaluation Indexes for Service Quality after Railway Re-Opening-Using the Old Mountain Line Railway as an Example. Recent Res. Syst. Sci. 2011, 1, 474-479.

41. Kosko, B. Fuzzy cognitive maps. Int. J. Man-Mach. Stud. 1986, 24, 65-75. [CrossRef]

42. Salmeron, J.L.; Vidal, R.; Mena, A. Ranking Fuzzy Cognitive Maps based scenarios with TOPSIS. Expert Syst. Appl. 2012, 39, 2443-2450. [CrossRef]

43. Felix, G.; Napoles, G.; Falcon, R.; Froelich, W.; Vanhoof, K.; Bello, R. A review on methods and software for fuzzy cognitive maps. Artif. Intell. Rev. 2017. [CrossRef]

44. Umweltbundesamt Austria. Fuzzy Cognitive Mapping-Das Werkzeug. Available online: http:/ / www.umweltbundesamt.at/umweltsituation/oekosystemareumweltkontrolle/mfrp_ eisenwurzen/projekte_eisenw/soz_oek_forsch/fcm/fcm_hinter/ (accessed on 9 October 2018).

45. Landeta, J.; Barrutia, J.; Lertxundi, A. Hybrid Delphi: A methodology to facilitate contribution from experts in professional contexts. Technol. Forecast. Soc. Chang. 2011, 78, 1629-1641. [CrossRef]

46. Gray, S.A.; Gray, S.; Cox, L.J.; Henly-Shepard, S. Mental Modeler: A Fuzzy-Logic Cognitive Mapping Modeling Tool for Adaptive Environmental Management. In Proceedings of the IEEE 46th Hawaii International Conference on System Sciences, Wailea, Maui, HI, USA, 7-10 January 2013. [CrossRef]

47. Stevenson, V. Some initial methodological considerations in the development and design of Delphi Surveys. In H-Delivery WP 3-Task 3.2: Characterisation of Prospective Technologies; Low Carbon Research Institute: Cardiff, UK, 2010; Available online: https://orca.cf.ac.uk/9949/1/Initial\%20methodological\% 20considerations\%20in\%20the\%20development\%20and\%20design\%20of\%20Delphi\%20surveys.pdf (accessed on 26 November 2018).

48. Hasson, F.; Keeney, S.; McKenna, H. Research guidelines for the Delphi survey technique. J. Adv. Nurs. 2000, 32, 1008-1015. [CrossRef]

49. Cheng, C.H.; Lin, Y. Evaluating the best main battle tank using fuzzy decision theory with linguistic criteria evaluation. Eur. J. Oper. Res. 2002, 142, 174-186. [CrossRef]

50. Gray, S.; Zanre, E.; Gray, S. Fuzzy Cognitive Maps as Representations of Mental Models and Group Beliefs. In Fuzzy Cognitive maps for Applied Sciences and Engineering-From Fundamentals to Extensions and Learning Algorithms; Papageorgiou, E.I., Ed.; Springer Publishing: Berlin, Germany, 2018.

51. Özesmi, U.; Özesmi, S.L. Ecological models based on people's knowledge: A multi-step fuzzy cognitive mapping approach. Ecol. Model. 2004, 176, 43-64. [CrossRef]

52. Eden, C.; Ackerman, F.; Cropper, S. The analysis of cause maps. J. Manag. Stud. 1992, 29, 309-323. [CrossRef]

53. Obiedat, M.; Samarasinghe, S.; Strickert, G. A New Method for Identifying the Central Nodes in Fuzzy Cognitive Maps using Consensus Centrality Measure. In Proceedings of the 19th International Congress on Modelling and Simulation, Perth, Australia, 12-16 December 2011; pp. 1084-1091.

54. Tavassoli, S. Analyzing Centrality Indices in Complex Networks: An Approach Using Fuzzy Aggregation Operators. Ph.D. Thesis, Kaiserslautern, Germany, 2018.

55. Dahlman, C.J. The Problem of Externality. J. Law Econ. 1979, 22, 141-162. [CrossRef]

56. Kambo, H.S.; Minaret, J.; Dutta, A. Process Water from the Hydrothermal Carbonization of Biomass: A Waste or a Valuable Product? Waste Biomass Valoriz. 2018, 9, 1181-1189. [CrossRef] 
57. Stutzenstein, P.; Weiner, B.; Köhler, R.; Pfeifer, C.; Kopinke, F.D. Wet oxidation of process water from hydrothermal carbonization of biomass with nitrate as oxidant. Chem. Eng. J. 2018, 339, 1-6. [CrossRef]

58. Köchermann, J.; Görsch, K.; Wirth, B.; Mühlenberg, J.; Klemm, M. Hydrothermal carbonization: Temperature influence on hydrochar and aqueous phase composition during process water recirculation. Environ. Chem. Eng. 2018, 6, 5481-5487. [CrossRef]

59. Cordell, D.; White, S. Peak Phosphorus: Clarifying the Key Issues of a Vigorous Debate about Long-Term Phosphorus Security. Sustainability 2011, 3, 2027-2049. [CrossRef]

60. Hsu, Y.-L.; Lee, C.-H.; Kreng, V.B. The application of Fuzzy Delphi Method and Fuzzy AHP in lubricant regenerative technology selection. Expert Syst. Appl. 2010, 37, 419-425. [CrossRef]

61. Kokkinos, K.; Lakioti, E.; Papageorgiou, E.; Moustakas, K.; Karayannis, V. Fuzzy Cognitive Map-Based Modeling of Social Acceptance to Overcome Uncertainties in Establishing Waste Biorefinery Facilities. Front. Energy Res. 2018, 6, 1-17. [CrossRef]

62. Helms, M.M.; Nixon, J. Exploring SWOT analysis-Where are we now? A review of academic research from the last decade. J. Strategy Manag. 2010, 3, 215-251. [CrossRef]

63. Rauch, P.; Wolfsmayr, U.J.; Borz, S.A.; Triplat, M.; Krajnc, N.; Kolck, M.; Oberwimmer, R.; Ketikidis, C.; Vasiljevic, A.; Stauder, M.; et al. SWOT analysis and strategy development for forest fuel supply chains in South East Europe. For. Policy Econ. 2015, 61, 87-94. [CrossRef]

64. Zadeh, L.A. Fuzzy sets. Inf. Control 1965, 8, 338-353. [CrossRef]

65. Hax, A.C.; Majluf, N.S. Competitive cost dynamics: The experience curve. Interfaces 1982, 12, 50-61. [CrossRef]

(C) 2018 by the authors. Licensee MDPI, Basel, Switzerland. This article is an open access article distributed under the terms and conditions of the Creative Commons Attribution (CC BY) license (http:/ / creativecommons.org/licenses/by/4.0/). 